\title{
Colonel Harding in remotest Barotseland. A review
}

\section{S. H. F. Capenny}

To cite this article: S. H. F. Capenny (1905) Colonel Harding in remotest Barotseland. A review, Scottish Geographical Magazine, 21:9, 484-490, DOI: 10.1080/00369220508733598

To link to this article: http://dx.doi.org/10.1080/00369220508733598

册Published online: 27 Feb 2008.

Submit your article to this journal 준

Џll Article views: 5

Q View related articles $\asymp$ 
Diaptomus wierzejskii, this being the most sonthern locality on the mainland where the type of the species has been observed by the Lake Survey, though it extends much further south in the Outer Hebrides, where Dr. Scott got it in Barra. The Rotifer Triarthra longiseta was also abundant.

\section{COLONEL HARDING IN REMOTEST BAROTSELAND. 1}

\section{A REVIEW.}

By S. H. F. Capenny.

THE name of Colonel Harding has now been associated for half a decade with Barotseland. When he assumed office in November 1899, the Barotse kingdom had become, at the request of King Lewanika, a British Protectorate. Its limits were undefined, if not unknown; and little was known about the greater part of the country. Colonel Harding had, therefore, been instructed to explore this new territory and report upon it. In his Remotest Barotseland he gives an account of four journeys, based on his notes from day to day. His book is therefore divided into four parts: the first deals with the course and source of the Zambezi; the second, with a journey from the Upper Zambezi to Bihe in Angola and thence to Lialui, the capital of Barotseland; the third, with a journey to the Batoka country, the Zambezi, and the Kafue; the fourth, with a visit to the source of the Kabompo. In the following account, this order will be followed.

Colonel Harding begins his account with his arrival at Kazungula, on the left bank of the Zambezi, some 38 miles above the Victoria Falls, and some 300 miles from Bulawayo. Kazungula has long been recognised as a drift or point for crossing the Zambezi, and can claim quite a historical reputation from the many invasions which have been made across the Zambezi there into the Barotse kingdom. "Kazungula," he says, "is by no means a sanatorium, but though unhealthy, the beauty of the 460 yards of water that divided us from the opposite bank was very great. The sunsets were glorious, lighting up the river as evening drew on with a glow of colour of exquisite variety and beauty. Occasionally we would sail out to pass an hour or two down the river reaches in a welting flood of crimson and gold in the west, the far-off cry of some wild bird alone breaking the glowing silence of the evening, while, in spite of the scene of romance and dreams around us, we would practically replenish our larder with the large tiger-fish which abound at this point, and make an excellent dish for the hungry traveller, eaten under the dim light of the stars and the brightness of our own cheery camp fires." Colonel Harding was accompanied by his

1 In Remotest Barotseland: Being an Account of a Journey of over 8000 miles through the Wildest and Remotest Parts of Lewanika's Empire. By Colonel Colin Harding, C.M.G., F.R.G.S., Acting-Administrator of North-West Rhodesia, Commandant Barotse Native Police. London: Hurst and Blackett, 1905. Pr. xv+413. Map of author's route, Price 10 s. 6 d. 
brother, Mr. W. Harding, who was acting as his secretary, and by $\mathrm{Mr}$. Gifford Moore, who came as accountant. As they had left the wagons a hundred miles in rear, having proceeded on horseback from Bulawayo to the Zambezi, Colonel Harding visited the Victoria Falls and the policestations in the Batoka country, leaving his companions at Kazungula. On his return the wagons arrived, and, after a delay of three weeks, the boats from Lewanika arrived for the ascent of the Zambezi, and along with them a note of welcome to Barotseland from the Rev. Mr. Coillard, the head of the "Paris Evangelical Mission" at Lialui. As Mr. Moore had been sent to the Batoka country, Colonel Harding and his brother began their ascent of the Zambezi on a bright November morning. The expedition consisted of twenty boats. The horses and mules had been sent overland a few days earlier in charge of Sergeant Macaulay of the British South Africa Police. On the second day, at sundown, Colonel Harding and his flotilla arrived at Sesheke, a distance of 55 miles from Kazungula. Sesheke is a mission station. It is very unhealthy, and "can with difficulty be surpassed as a deadly malarious hotbed." There he found Sergeant Macaulay prostrate with fever. Putting him, therefore, in his own boat, Colonel Harding took his place with the horses and pack mules and travelled to Lialui overland. On the day of his arrival at Mongu, the British Residency, near Lialui, he received a letter from Lewanika welcoming him to Barotse. "The king," he says, when he paid his first visit to Lewanika, "was arrayed in an alpaca coat, fancy waistcoat, brown boots and trousers, and a black felt hat; he met me outside the court-house, deferentially, and with a dignity of mien which much surprised me, and politely welcomed me, and bade me precede him." Colonel Harding had been at Lialui a week when his brother and Macaulay arrived with the boats.

After writing several reports and getting the camp put into shape, he left Macaulay in charge, and set out to visit the Upper Zambezi. The king provided twelve boats, sent some of his indunas, and took advantage, as was intended, of Colonel Harding's visit to send messages to his vassals. For this purpose a phonograph was used, and this instrument, when it sounded forth the words of Lewanika, afforded unbounded surprise. It was also used to receive their professions of fealty to Lewanika. It was on January 19, 1900, that everything was ready for the start up the Zambezi; the objectives in the first part of the journey were Kakengi and Nyakatoro, the two principal stations, about 320 miles up the river. At that season the Zambezi is in flood, inundating the Barotse valley. After three days they were fairly out of the Barotse valley, and wholly out of it after six days. No obstruction was met with till the Sapuma rapids were reached. Throughout his journey Colonel Harding summoned the chiefs along his route. One of the first was Mokengi, a brother of Kakengi. "I had not yet seen the Kakengi," says Colonel Harding, "but if at all like his brother, I felt their parents must be unfortunate to an exceptional degree, for a truer type of a Caliban it has never yet been my misfortune to meet. The teeth were filed to sharp points, and after a sentence come together like a rat-trap; his brow receded, his chin ran away from his face, his 
shoulders sloped like a champagne bottle, and altogether a more repulsive, ill-formed, and grotesque being I have never met." His conduct did not belie this anticipation of his character; and his brother, Kakengi, proved to be even worse: "Kakengi himself is a middle-aged man of medium height, with the bloated appearance of the habitual drunkard. During his paroxysms of drink he is capable of most ferocious deeds and hideous atrocities. At these times his brutality is notorious, and only equalled by his immorality." When Kakengi was created governor of the district, however, by Lewanika, he was a sober and, for a native, an industrious man; but within the last few years he had developed into a dipsomaniac, craving for his Kaffir beer and Portuguese brandy. At

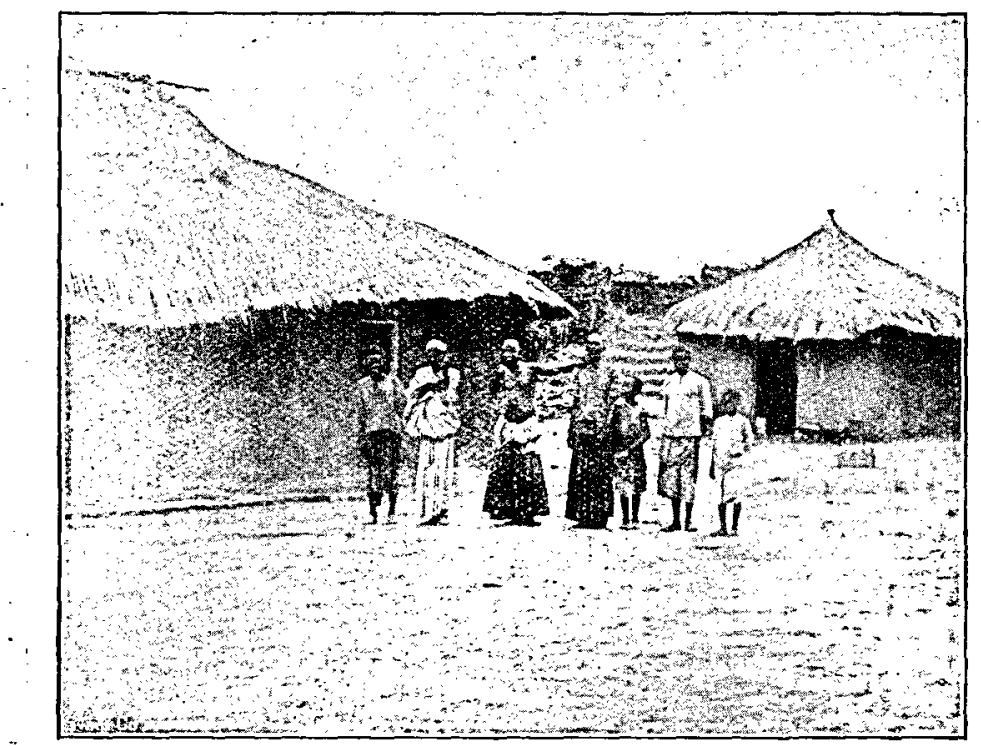

Fia. 1.-Valovale Chiefs at Nyakatoro.

Kakengi Colonel Harding first met one of the Portuguese commandants, with whom, as throughout his journey, he kept up friendly relations, but obtained assurances of Kakengi's fealty to Lewanika. After some weeks, during which the country was explored and mapped, a new start was made. Colonel Harding had chosen the rainy season for his journey, and was thus able to utilise the Zambezi; but his account of the hardships tells for the dry season. "Those alone," he writes, when on his way to Kakengi," who have travelled during a wet season in tropical Africa can fully picture or realise the discomforts and hardships with which one has to combat in that time. Everything is in a soaked and sodden condition. One's clothes are never dry, one's food ferments and perishes, and one's steps are constantly dogged by the persistent and venomous malarial microbe. Quinine you take as regularly as your 
dinner when in England, and your spirits sink to the lowest ebb of despondency and despair. The servants and carriers (or, as in our case, the rowers) are either unable or too lazy to perform the round of their duties, and though perhaps provided with two cooks, you have to perform the culinary work yourself as often as not, however tired out in condition or temper." Kazombo, a mission station, was the next place of any importance after Kakengi, and thence it was some 30 miles overland to Nyakatoro. Colonel Harding hoped to use the river, but was obliged to abandon it after a while and strike across country. Nyakatoro is the capital of the Valovale and the residence of the Queen; it is an important place in relation to the great trade route to the West Coast. It is a mission station and also a Portuguese fort. As it is generally believed that the Barotse came from the south of the Zambezi, it is worthy of note that, according to the tradition of Nyakotoro, the Queen and Lewanika are blood relations, and are descended from a royal house which formerly lived near Lake Dilolo and the Kasai River.

On the 5th of March Colonel Harding left the Valovale country to visit the source of the Zambezi. He now passed through the territory of the Malunda tribe. They are quite distinct both in language and costume from the Valovale; they do not recognise Nyakatoro's authority, but acknowledge as their chief Shinti, an induna who lives on the Kabompo and is a vassal of Lewanika's. After one failure in locating the source of the Zambezi, Colonel Harding succeeded in achieving his quest. "The source," he says, "is composed of numerous springs, surrounded with a jungle of luxuriant trees interlaced with thick creepers, tall bracken, and many and various plants adapted to a wet and heavily shaded soil. Fungus grows abundantly, and its vivid scarlet contrasts brilliantly with the dark soil and the deep green of the heavy foliage. The height of the source reads at about 5200 feet, and a more healthy spot could hardly be imagined." Colonel Harding then returned overland 240 miles to Nyakatoro, having travelled 1145 miles since leaving Kazungula. He estimates the distance from the Victoria Falls to the source of the Zambezi at 943 miles; Victoria Falls to Kazungula, 38 miles ; Kazungula to Sesheke, 55 ; Sesheke to Lialui, 230 ; Lialui to Nyakatoro, 320 ; Nyakatoro to the source of the Zambezi, following the river, 300 .

On Good Friday, 13th April, Colonel Harding left Nyakatoro for Chisamba Bihe in Angola, a distance of 560 miles. It was his aim to interview all important chiefs along the route, visit the Portuguese forts, and report generally on the country. The general direction of his route followed the great highway of trade which has long been used by the Mambari of the West Coast, the Garanganze route to Katanga. The route passes through Kalunga Kameya (255 miles), Mosiko Fort (64), Matota Fort (125), Quanza Fort (43), Chisamba Mission Station (35), which is a small village at Bihe composed wholly of the American Mission and its Christian natives. On his way to Lialui from Chisamba he passed through Kalomo, 356 miles, and thence 212 miles to Lialui, where he arrived on the 20th of June. During this journey he trekked $55 \frac{1}{2}$ days, making a daily average of 19.6 miles. The Baluchazi was the most important tribe, and their country is noteworthy for its produce of 
rubber. "The Baluchazi," he says, "are a finer race than the Valovale: The women wear their hair long, coming down two or three inches each side of their head; on the top it is ornamented with small sea-shells. They have intelligent faces, without the thick lips and broad nostrils so noticeable in natives as a rule. Their necks are covered with red beads, and their ankles encircled with brass anklets. The principal fare is mealies, or chovongo, as the Biheans term it." The day after his arrival at Lialui, Lewanika and his principal indunas came over to thank him for taking the journey, and to congratulate him on his safe return. "No other chief," said Lewanika, "has seen my country like you, and from my heart I thank you." On his return journey, Colonel Harding was met at Kalomo by Sergeant Macaulay, who has since been promoted, having

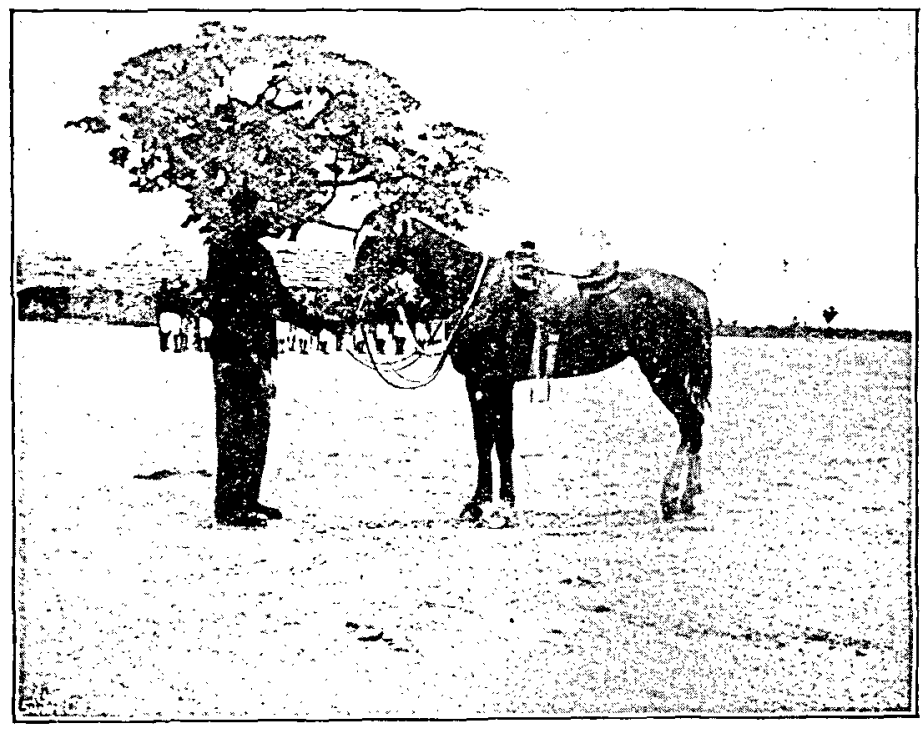

FIG. 2.-Breakfast : Col, Harding's Native Mounted Servant.

obtained a commission in the Barotse Native Police, and been appointed District Commissioner at Kasempa.

Colonel Harding's third journey, from July to September 1900, led from Lialui to the Victoria Falls and thence to Kalomo and Monze in the Batoka country, then along the Zambezi and the Kariba gorge to the Kafue, and up the Kafue to visit the Balungwe or Mahuminia Falls or Rapids. The Batoka tableland is some 50 miles square, wellfitted for farming, with good water, good grazing, excellent shooting, and the healthiest of climates, in a district some 4500 feet in altitude. In this journey, Colonel Harding was accompanied by a mounted native servant, Breakfast, "superbly dressed, immaculately clean, and possessing a wardrobe, the wonder of his companions and envy of myself." The natives on the river are Batonga, and are quite distinct from the Batoka. 
The Bantua are another river-tribe along the Zambezi. From the junction of the Kafue and the Zambezi Colonel Harding proceeded to visit the Balungwe Falls. These are rather rapids or cataracts, with a picturesque graduating. descent of two miles. "The river, here," he says, "some 150 yards wide, is a white boiling mass, a roaring, dashing torrent, leaping over huge bouldered terraces, rushing madly between insurmountable rocks, watering the foliferous plants that gratefully thrive by the river brink, forming a pleasing contrast to the parched and stunted shrubs that struggle for an existence in the rocky subsoil up the river." After leaving the Falls he arrived in two days in Mashukulumbwe country.

When he left Lialui in June, Colonel Harding had arranged to meet his brother at Nkala in order to visit the source of the Kafue, pass thence

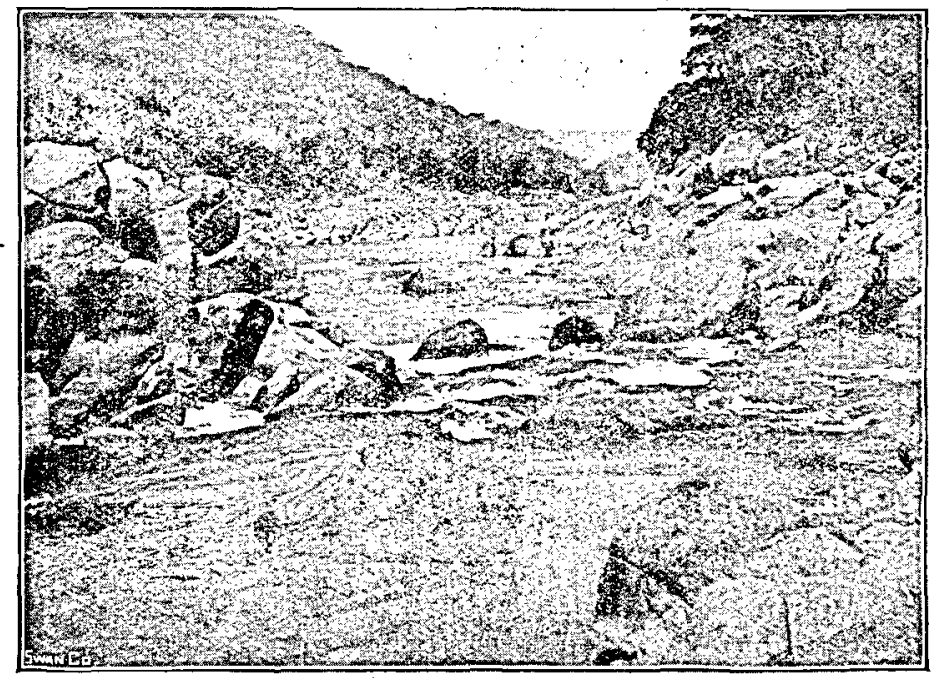

FIG. 3.-Balungwe or Mahuminia Fajls or Rapids, Kafue River.

to that of the Kabompo, and then return to Lialui. It was now necessary, however, to proceed to Lialui, some 270 miles from Nkala, in order to meet Mr. Coryndon, the Resident. Colonel Harding then decided to visit the source of the Kabompo. He proceeded to Kasempa, 250 miles, and thence to the source of the Kabompo, some 200 miles, which is not unlike that of the Zambezi, surrounded with luxuriant vegetation in the midst of a huge thicket of dense trees. "I consider," says Colonel Harding, "the watershed of the Zambezi and Congo rivers a district that will repay the greatest attention, and if mineral wealth is to be found in West Central Africa it will be located in these parts."

It was in October that Colonel Harding left Lialui for the source of the Kabompo, and it was the end of January before he returned, after covering some 2000 miles. After remaining a while at Lialui, the only rest since he had arrived ejghteen months before, he left for the Batoka

VOL. $\mathrm{XXI}$. 
country in February. On arriving at Kazungula he heard of the illness of his brother, who, after their parting at Nkala, had visited the copper mines east of the Kafue, and when halfway between the Falls and Monze he heard of his brother's death.

When Colonel Harding was home for a holiday in England, King Lewanika had been invited to the coronation of King Edward, and the duty devolved on Colonel Harding of accompanying the Barotse king both during his stay in England, and his journey to Barotseland. Colonel Harding in his last chapter gives an appreciative account both of the Barotse king during this time, and of the statesmanlike character of Lewanika.

Colonel Harding's book is a most vivid and fresh account of these remote parts of the empire. Based as it is on his notes day by day, it enables the reader to follow the life and work of those who amid many hardships are engaged in Britain's imperial work, and to behold those little known lands and peoples through the mind of an officer and gentleman. ${ }^{1}$

\section{A GREAT GEOGRAPHER: ELISÉE RECLUS, 1830-1905.}

\section{By Professor Patrick Gedves.}

I.

THE writing of biography is plainly one of those fields which must longest await reduction to scientific methods. Here most of all, amongst the puzzles of evolution, the difficulty seems supreme, the complexity greatest. Each individual is at his best unique, and the great man is a culminating product of past tendencies and forces, all hard to unravel, and perhaps yet harder to estimate at their respective importance, whether for him or for the world. Such in fact is the many-sidedness of every full life, every developing and varied career, that we may have as many biographies as there chance to be biographers, perhaps as many fresh interpretations of these as they find reflective readers. Yet here is no mere confusion, but the early struggle of what may be developed into distinct methods of biographic treatment, and these only in appearance rival ones. In the study of lower forms of life the first investigator gives himself especially to the task of formal and outward description of the adult organism as he sees it; another dissects, another classifies. Soon, however, some other complements these presentments-all too static-by inquiries into the inward life and its functioning; another by a study of the life in its wider outward relations to its fellows, its struggle of love and hunger amid the great world-its whole environment, in short. But none of these investigators is as yet fully an evolutionist; hence new schools of workers must take up the task. One reinvestigates the developments of individual infancy, or of such metamorphoses as that which in our own species we

1 The illustrations accompanying this paper are from Colonel Harding's book, and we are indebted to the publishers for the use of the blocks. 